\title{
Tingkat Pendapatan Dan Pola Konsumsi Petani Karet Di Desa Marga Sakti Kecamatan Muara Kelingi Kabupaten Musi Rawas
}

\section{Level Of Income and Consumption Of Rubber Farmers In Marga Sakti Village, Muara Kelingi Musi Rawas District}

\author{
${ }^{1}$ May Shiska Puspitasari , ${ }^{2}$ Zaini Amin, ${ }^{3}$ Anton Arfandi \\ ${ }^{122) 3)}$ Program Studi Agribisnis Fakultas Pertanian Universitas Musi Rawas \\ *E-mail : may270584@gmail.com
}

\begin{abstract}
This study aims to determine the relationship between farmer income levels and consumption patterns of rubber farmers. This research was conducted in Marga sakti Village, Muara Kelingi District, Musi Rawas Regency from April to July 2016. This study used a survey method with deliberate location determination, while the sampling method was carried out by the method (Proportionate Stratified Random Sampling) in which the population farmers who carry out rubber farming and oil palm farming in Marga Sakti Village, which amounted to 325 family heads were taken by 33 heads of households as samples. The results of this study indicate that the average household income level is Rp. 87,138,497 per year sourced from rubber farming $R p$. 32,444,000 per year or 45\%, and rubber and palm farming $R p$. $54,694,286$ per year or $55 \%$. With 55\% of income derived from rubber and oil palm farming, this area is included in food insecure areas and the higher the level of income, the nonsignificant proportion of carbohydrate food will increase and significantly there is a tendency to increase the proportion of expenditure on non-carbohydrates and non-food
\end{abstract}

Keywords: Income, Consumption Pattern

Disubmit : 3 Januari Diterima: 13 Februari Disetujui :28 Maret

\section{PENDAHULUAN}

Luas areal tanaman karet di Indonesia pada tahun 2014 adalah 3.606.245 ha dengan produksi 3.153.186 ton karet kering pertahun. Produksi karet terbesar disumbangkan oleh daerah Sumatra dan Sumatra Selatan merupakan salah satu daerah penghasil karet kering dengan luas lahan 822.698 ha dengan produksi 900.769 ton. Produksi tersebut datang dari berbagai daerah di Sumatra Selatan, satu diantaranya dari Kabupaten Musi Rawas (Direktorat Jenderal Perkebunan, 2014).

Kabupaten Musi Rawas merupakan salah satu daerah penghasil karet di Sumatra Selatan. Luas areal perkebunan karet di Kabupaten Musi Rawas 333.282,05 ha dengan produksi 263.246,54 ton per tahun, kebun karet di Kabupaten Musi Rawas secara keseluruhan merupakan perkebunan rakyat, sehingga sebagian besar masyarakat memperoleh pendapatan dari kebun karet ([BPS] Badan Pusat Statistik., 2013). Tingginya tingkat pendapatan rumahtangga tidak selalu diikuti oleh perbaikan gizi dalam pola konsumsinya. Secara umum dengan adanya peningkatan pendapatan akan memberi peluang bagi masing-masing rumahtangga untuk melakukan diversifikasi konsumsi untuk meningkatkan kualitas pangan pokok dalam upaya meningkatkan gizi keluarganya (Suyastiri, 2008)

Konsep kesejahteraan terkait erat dengan kebutuhan dasar manusia. Secara sederhana seorang atau keluarga dikatakan sejahtera jika telah terpenuhi kebutuhan dasarnya. Maslow menjelaskan terdapat hierarki kebutuhan manusia yang dimulai dari kebutuhan dasar, kebutuhan keamanan dan keselamatan, kebutuhan penghargaan, dan kebutuhan aktulisasi diri (Hasibuan, 2012). Hal ini sejalan dengan Hukum Engel 
menjelaskan bahwa rumahtangga yang mempunyai upah atau pendapatan rendah akan mengeluarkan sebagian besar pendapatannya untuk membeli kebutuhan pokok. Sebaliknya, rumahtangga yang berpendapatan tinggi akan membelanjakan sebagian kecil saja dari total pengeluaran untuk kebutuhan pokok. Berdasarkan teori klasik ini, maka rumahtangga bisa dikatakan lebih sejahterah bila persentase pengeluaran untuk makanan jauh lebih kecil dari persentase pengeluaran untuk bukan makanan. Artinya proporsi alokasi pengeluaran untuk pangan akan semakin kecil dengan bertambahnya pendapatan rumahtangga, karena sebagian besar dari pendapatan tersebut dialokasikan pada kebutuhan non pangan.

Konsumsi merupakan suatu pengeluaran manusia mengurangi atau menghabiskan nilai guna suatu barang atau jasa untuk memenuhi kebutuhan, baik secara berangsur-angsur maupun sekaligus. Makin besar pengeluaran untuk konsumsi barang dan jasa maka makin tinggi tahap kesejahteraan keluarga tersebut. Salah satu strategi untuk meningkatkan kesejahteraan masyarakat miskin adalah menurunkan ketidakberdayaan penduduk terhadap kebutuhan yang fundamental seperti makanan, sandang, papan, kesehatan dan gizi (Cicih, 2011). Kekurangan konsumsi terutama pangan erat kaitannya dengan kemiskinan. Menurut De Vos, miskin adalah suatu keadaan seseorang mengalami kekurangan atau tidak mampu memenuhi kebutuhan yang paling rendah atau tidak mampu mencapai tingkat minimal dari tujuan-tujuan yang telah ditetapkan, dapat berupa konsumsi, kebebasan, hak mendapatkan sesuatu, menikmati hidup dan lain-lain.

Marga Sakti merupakan salah satu desa di Kecamatan Muara Kelingi Kabupaten Musi Rawas yang mayoritas penduduknya mengusahakan perkebunan karet, dan sawit dengan kepemilikan luas lahan yang sama tetapi dengan jumlah produksi yang berbeda-beda antara petani satu dengan petani lainnya, hal ini dikarenakan terjadinya perbedaan perawatan dan pemupukan antara petani satu dengan petani lainnya. Kondisi ini menyebabkan terjadinya perbedaan tingkat pendapatan antara petani. Akibatnya menimbulkan pola konsumsi rumahtangga yang berbeda-beda. Seperti yang dijelaskan Gossen dalam Kadariah, (2002) apabila pendapatan meningkat, seseorang dapat mengkonsumsi barang dalam jumlah yang lebih banyak, namun tidak semua pendapatan digunakan untuk konsumsi, akan tetapi bagi seseorang yang memiliki kelebihan untuk konsumsi digunakan untuk menabung. Berdasarkan uraian diatas, maka dipandang perlu untuk dilakukan penelitian tentang "Tingkat Pendapatan dan Pola Konsumsi Petani Karet di Desa Marga Sakti Kecamatan Muara Kelingi Kabupaten Musi Rawas" adapun tujuan yang ingin dicapai dalam penelitian ini adalah untuk mengetahui hubungan tingkat pendapatan petani dan pola konsumsi petani karet.

\section{METODE PENELITIAN}

\section{Tempat dan Waktu Penelitian}

Penelitian ini dilaksanakan di Desa Marga Sakti Kecamatan Muara Kelingi Kabupaten Musi Rawas, pengambilan data dilaksanakan pada bulan April sampai Juli 2016.

\section{Metode Penelitian}

Metode penelitian yang digunakan adalah metode survei. Penelitian survei merupakan usaha pengamatan untuk mendapatkan data dan fakta yang jelas terhadap suatu masalah tertentu dalam suatu penelitian. Untuk memperoleh data dan fakta dilapangan tersebut adalah menggunakan petani sampel, sedangkan penentuan lokasi dilakukan dengan pertimbangan bahwa di Desa Marga Sakti mayoritas masyarakatnya bergerak dalam bidang usahatani karet.

\section{Metode Penarikan Sampel}

Metode penarikan sampel yang digunakan dalam penelitian ini adalah metode acak berlapis berimbang (Proportionate Stratified Random Sampling) dan disajikan pada tabel di bawah ini.

Tabel 1. Jumlah Kepala Keluarga (KK) petani berdasarkan komoditi yang diusahakan di Desa Marga Sakti Kecamatan Muara Kelingi.

\begin{tabular}{llcc}
\hline No & $\begin{array}{l}\text { Jenis komoditi yang } \\
\text { diusahakan }\end{array}$ & Jumlah Populasi & $\begin{array}{c}\text { Jumlah Petani Sample } \\
(\%)\end{array}$ \\
\hline 1 & Karet & 186 & 19 \\
2 & Karet \& Sawit & 139 & 14 \\
\hline & Jumlah & 325 & 33 \\
\hline
\end{tabular}


PadaTabel 1Jumlah petani karet $186 \mathrm{KK}$, karet dan sawit $139 \mathrm{KK}$, sehingga total populasi $325 \mathrm{KK}$ dan masing-masing dari populasi diambil sampel sebanyak $10 \%$ dan didapat jumlah petani sampel sebanyak 33 orang.

\section{Metode Pengumpulan Data}

Data yang digunakan dalam penelitian ini adalah data primer dan data sekunder, dimana data primer diperoleh dari hasil wawancara langsung dengan petani karet di Desa Marga sakti Kecamatan Muara Kelingi Kabupaten Musi Rawas sebagai responden penelitian. Dengan tuntunan kuisoner atau daftar pertanyaan. Sedangkan data sekunder diperoleh dari sumber-sumber yang berkaitan dengan penelitian ini seperti data dari dinas atau instansi terkait serta laporan terdahulu yang menunjang penelitian ini.

\section{Metode Pengolahan Data dan Analisis Data}

Data yang diperoleh dilapangan selanjutnya diolah dengan metode tabulasi, untuk kemudian dijelaskan secara deskriptif. Data yang diolah kemudian dianalisis secara matematis sehingga diperoleh gambaran tentang pendapatan dan pola pengeluaran petani keret.

\section{Pendapatan}

Untuk menghitung pendapatan petani responden digunakan rumus sebagai berikut:

$\mathrm{Pd} \quad=\mathrm{Pd}$ on $+\mathrm{Pd}$ oF

Keterangan :

$\mathrm{Pd} \quad=$ Pendapatan rumahtangga petani karet (rupiah)

Pdon = Pendapatan dari usahatani karet (rupiah)

PdoF = Pendapatan dari luar usahatani karet (rupiah)

\section{Pengeluaran Petani}

Untuk menghitung total pengeluaran rumahtangga petani dapat diketahui dengan menghitung pengeluaran pangan dan non pangan dengan mengunakan rumus :

$\mathrm{Tc} \quad \mathrm{Cp}+\mathrm{Cn}$

Keterangan :

Tc : Total Pengeluaran (rupiah)

$\mathrm{Cp} \quad$ : Pengeluaran pangan (rupiah)

$\mathrm{Cn} \quad$ : Pengeluaran non pangan (rupiah)

\section{Proporsi Pengeluaran Pangan dan Non Pangan}

Untuk mengetahui proporsi pengeluaran untuk pangan, maka digunakan persamaan sebagai berikut :

$\mathrm{Pp}=\mathrm{cp} /(\mathrm{TC}) \times 100 \%$

Keterangan :

$\mathrm{Pp} \quad$ : Proporsi pengeluaran pangan (\%)

$\mathrm{Cp} \quad$ : Pengeluaran pangan (rupiah)

TC : Total pengeluaran (rupiah)

Untuk mengetahui proporsi pengeluaran non pangan maka digunakan persamaan sebagai berikut :

$\mathrm{Ppn}=$ [CP $\rrbracket \_\mathrm{n} /(\mathrm{TC}) \times 100 \%$

Keterangan :

Ppn : Proporsi pengeluaran non pangan (\%)

Cpn : Pengeluaran non pangan (rupiah)

TC : Total pengeluaran (rupiah)

\section{Pola Konsumsi Pangan dan Non Pangan}

Untuk mengetahui seberapa jauh hubungan tingkat pendapatan terhadap pola konsumsi pangan (pangan karbohidrat dan pangan non karbohidrat) dan non pangan, maka dirumuskan persamaan sebagai berikut:

$\mathrm{Yi}=\mathrm{ai} . \mathrm{Xbi}$ 
Untuk mempermudah persamaan regresi tersebut maka persamaan ditransformasikan kedalam bentuk logaritma, sehingga persamaannya adalah sebagai berikut:

$\operatorname{Ln} \mathrm{Y} 1=\ln \mathrm{a} 1+\mathrm{b} 1 \ln \mathrm{X}$

$\operatorname{Ln} \mathrm{Y} 2=\ln \mathrm{a} 2+\mathrm{b} 2 \ln \mathrm{X}$

$\mathrm{Ln} \mathrm{Y} 3=\ln \mathrm{a} 3+\mathrm{b} 3 \ln \mathrm{X}$

Keterangan :

Y1 = Pengeluaran pangan karbohidrat (rupiah)

Y2 = Pengeluaran pangan non karbohidrat (rupiah)

Y3 = Pengeluaran non pangan (rupiah)

$\mathrm{X}=$ Tingkat pendapatan (rupiah)

ai $\quad=$ Konstanta

bi $\quad=$ Koefisien regresi

\section{HASIL DAN PEMBAHASAN}

Pendapatan Rumahtangga Petani

Pendapatan Rumahtangga responden sebagian besar bersumber dari usahatani karet dan usahatani karet dan sawit. Pendapatan petani responden menurut sumber pendapatan disajikan pada Tabel 2 di bawah ini.

Tabel 2. Pendapatan Rumahtangga Petani

\begin{tabular}{llccc}
\hline No & Uraian & $\begin{array}{c}\text { Jumlah } \\
(\mathrm{Rp})\end{array}$ & $\begin{array}{c}\text { Rata-Rata } \\
(\mathrm{Rp})\end{array}$ & Persentase \\
\hline 1 & Usahatani karet & 616.440 .000 & 32.444 .211 & 45 \\
2 & Usahatani Karet dan Sawit & 765.720 .000 & 54.694 .286 & 55 \\
\hline & Total & 1.382 .160 .000 & 87.138 .497 & 100
\end{tabular}

(Sumber : Data Olahan Hasil Penelitian, 2016)

Pada tabel 2 di atas menjelaskan bahwa tingkat pendapatan petani responden rata-rata $\mathrm{Rp} 87.138 .497$ per tahun. Pendapatan tersebut bersumber dari usahatani karet, usahatani sawit dan karet dan usahatani lainya. Pendapatan dari usahatani karet rata-rata Rp 32.444.211atau $45 \%$ dari total pendapatan, sedangkan untuk pendapatan usahatani karet dan sawit rata-rata $\mathrm{Rp} 54.694 .286$ atau $55 \%$ dari total pendapatan. Sumber pendapatan dari usahatani karet yaitu sumber pendapatan petani yang berasal dari usahatani karet,sedangkan pendapatan petani karet dan sawit bersumber dari usahatani karet dan usahatani sawit.

Pendapatan adalah suatu hasil yang di dapatkan oleh seseorang setelah melakukan pekerjaan walaupun hasil yang dicapainya masih rendah ataupun sudah cukup tinggi yang nantinya digunakan untuk mencukupi suatu kebutuhan ataupun mengkonsumsi suatu barang dan jasa. Pada umumnya keluarga yang berpenghasilan rendah, proporsi yang besar dari pendapatanya akan digunakan sebagai kebutuhan makan. Hal ini sejalan dengan dengan pendapatnya Ernest Engel yang mengemukakan hukum" hubungan antara pendapatan dan konsumsi", bahwa makin besar pendapatan maka makin besar bagian pendapatan yang digunakan untuk konsumsi, terutama makanan dan sebaliknya.

Hasil perhitungan menunjukan bahwa pendapatan petani Rp. 1.382.160.000. Terdiri dari $45 \%$ dari usahatani karet, $55 \%$ dari usahatani karet dan sawit. Besarnya pendapatan yang akan diperoleh dari suatu kegiatan usahatani tergantung dari beberapa faktor yang mempengaruhinya seperti luas lahan, tingkat produksi, identitas pengusaha, pertanaman, dan efisiensi penggunaan tenaga kerja. Dalam melakukan kegiatan usahatani, petani berharap dapat meningkatkan pendapatannya sehingga kebutuhan hidup seharihari dapat terpenuhi. Harga dan produktivitas merupakan sumber dari faktor ketidakpastian, sehingga bila harga dan produksi berubah maka pendapatan yang diterima petani juga berubah.

Dari sisi kesejateraan tingkat pendapatan petani karet dan sawit tergolong tinggi. Melihat dari tingkat kemiskinan didasarkan jumlah rupiah pengeluaran Rumahtangga yang disetarakan dengan jumlah kilogram konsumsi beras per orang per tahun dan dibagi wilayah pedesaan dan perkotaan (Criswardani S., 2005). Daerah perdesaan :

a. Miskin, bila pengeluaran keluarga lebih kecil daripada $320 \mathrm{~kg}$ nilai tukar beras per orang per tahun. 
b. Miskin sekali, bila pengeluaran keluarga lebih kecil daripada $240 \mathrm{~kg}$ nilai tukar beras per orang per tahun.

c. Paling miskin, bila pengeluaran keluarga lebih kecil daripada $180 \mathrm{~kg}$ nilai tukar beras per orang per tahun.

Daerah perkotaan:

a. Miskin, bila pengeluaran keluarga lebih kecil daripada $480 \mathrm{~kg}$ nilai tukar beras per orang per tahun.

b. Miskin sekali: bila pengeluaran keluarga lebih kecil daripada $380 \mathrm{~kg}$ nilai tukar beras per orang per tahun.

c. Paling miskin, bila pengeluaran keluarga lebih kecil daripada $270 \mathrm{~kg}$ nilai tukar beras per orang per tahun.

Berdasarkan uraian di atas melihat dari pendapat Criswardani Suryawati, 2005 bahwa di katakan masyarakat miskin untuk di perdesaan bila di setarakan untuk konsumsi beras yaitu sebesar $320 \mathrm{~kg}$ pertahun dan untuk konsumsi beras di perkotaan yaitu sebesar $480 \mathrm{~kg}$ pertahun. Bila dibandingkan dengan pendapatan responden Rp. 41.883.636 per tahun menunjukan bahwa tingkat pendapatan petani karet dan petani sawit pertahun setara dengan 4.495 kilogram, yang berarti untuk konsumsi beras pertahun petani jauh lebih tinggi dari penggolongan kesejahteraan berdasarkan tingkat pendapatan yang ditentukan (Criswardani S., 2005). Sedangkan bila di ukur berdasarkan perkapita konsusmi beras untuk petani yaitu sebersar $113 \mathrm{~kg}$ perkapita, bila di bandingkan ukuran perkapita Kabupaten Musi Rawas sebesar 110 kg perkapita, maka untuk konsumsi beras petani responden jauh lebih tinggi.

Berdasarkan uraian di atas, selanjutnya dapat dijelaskan bahwa dengan tingkat pendapatan yang tinggi, telah menempatkan petani karet dan sawit sebagai masyarakat yang mempunyai daya beli yang tinggi. Namun demikian, karena sebelumnya dijelaskan sebelumnya bahwa $55 \%$ pendapatan masyarakat tergantung pada usahatani karet dan sawit akan memposisikan daerah ini sebagai daerah yang berpontensi rawan pangan. Dikatakan demikian, karena perekonomian negara-negara pengimpor karet dan sawit memburuk dan permintaan karet dan sawit menurun, maka harga karet dan sawit juga akan menurun. Akibatnya daya beli turun, yang berakibat kepada petani karet dan sawit, sehingga kemampuan untuk memenuhi kemampuan kebutuhan pangan menurun.

\section{Pola Pengeluaran Konsumsi Petani}

Pola konsumsi rumahtangga petani terdiri dari konsumsi pangan dan non pangan, pada pola konsumsi pangan dibagi menjadi konsumsi pangan karbohidrat dan non karbohidrat. Pola konsumsi petani karet dan petani sawit dapat dilihat pada Tabel 3 di bawah ini secara rinci dijelaskan pada tabel berikut.

\section{Tabel 3. Pola Konsumsi Petani Karet Dan Petani (karet dan sawit)}

\begin{tabular}{llccc}
\hline No & Uraian & $\begin{array}{c}\text { Jumlah } \\
(\mathrm{Rp})\end{array}$ & $\begin{array}{c}\text { Rata-rata } \\
(\mathrm{Rp})\end{array}$ & Proporsi \\
\hline 1 & Pangan Karbohidrat & 141.540 .000 & 4.289 .091 & 21 \\
2 & Pangan Non Karbohidrat & 279.952 .000 & 8.483 .394 & 41 \\
3 & Non Pangan & 256.846 .500 & 7.783 .227 & 38 \\
\hline \multicolumn{2}{l}{ Total } & 678.338 .500 & 20.555 .712 & 100 \\
\hline
\end{tabular}

(Sumber: Data Olahan Hasil Penelitian, 2016)

Dari Tabel 3 di atas diperoleh hasil rata-rata pengeluaran pangan karbohidrat Rp. 4.289 .091 per tahun atau $21 \%$, pangan non karbohidrat Rp. 8.483.394 per tahun atau $41 \%$ dan untuk pengeluaran non pangan Rp. 7.783.227 pertahun atau $38 \%$,Hal ini menunjukan bahwa proporsi konsumsi Non Karbohidrat lebih besar di bandingkan proporsi konsumsi untuk pangan karbohidrat, dan non pangan. Proporsi konsumsi untuk setiap jenis pengeluaran dalam penelitian ini merupakan presentase rata-rata konsumsi petani responden baik konsumsi pangan (beras, non beras, ikan, daging, telur, susu, sayur, kacang, buah, minyak, bahan pelengkap, makanan jadi, minuman jadi, rokok, perumahan, pembelian barang dan jasa, biaya pendidikan, biaya kesehatan, biaya pakaian, barang tahan lama, pengeluaran pajak, dan keperluan pesta dan upara adat). Proporsi setiap jenis konsumsi dapat dilihat pada gambar 1 dibawah ini. 


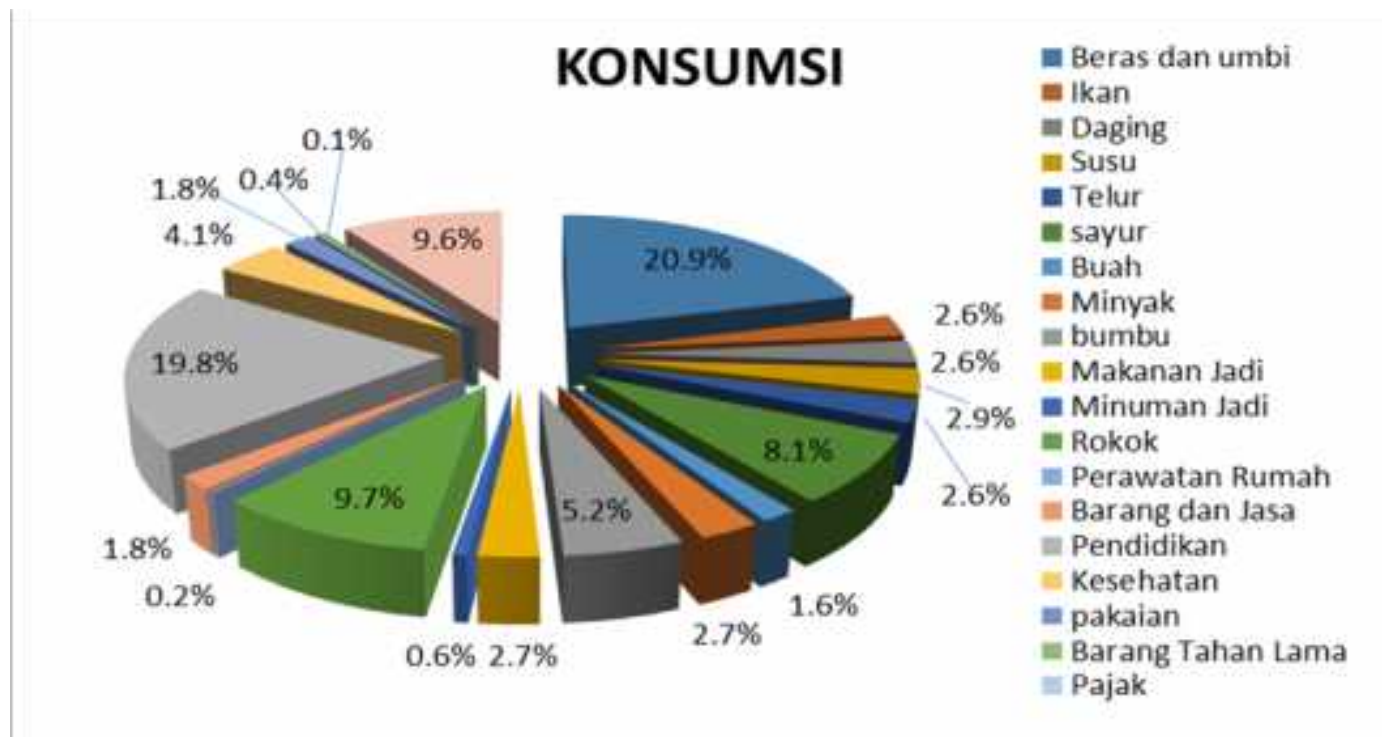

Gambar 1. Proporsi Setiap Jenis Pengeluaran Petani Karet dan Petani Sawit

Pada Gambar 1 menunjukan bahwa pengeluaran tertinggi petani responden dalam penelitian ini adalah biaya beras yaitu sebesar $20,9 \%$ dari total pengeluaran, kemudian diikuti dengan pengeluaran untuk pendidikan sebesar 19,8\% dan pengeluaran untuk rokok sebesar 9,7\%.

\section{Pengaruh Pendapatan terhadap Pola Konsumsi Petani}

Pengaruh pendapatan terhadap konsumsi rumahtangga terbagi menjadi tiga yaitu pengaruh terhadap konsumsi pangan, konsumsi non karbohidrat dan konsumsi non pangan, untuk melihat pengaruh pendapatan terhadap pola konsumsi dapat dilihat pada tabel dibawah ini.

\section{Tabel 4. Hasil analisis Pengaruh tingkat pendapatan terhadap pola konsumsi rumahtangga}

\begin{tabular}{cllllll}
\hline Source & $\begin{array}{l}\text { Dependent } \\
\text { variabel }\end{array}$ & Constant & $\begin{array}{l}\text { Koefisien } \\
\text { regresi }\end{array}$ & $\begin{array}{l}\text { R } \\
\text { squer }\end{array}$ & Df & Sig \\
\hline \multirow{5}{*}{ Pendapatan } & Karbohidrat & 13,199 & 0,115 & 0,026 & 1 & 0,368 \\
& Non Karbohidrat & 8,671 & 0,413 & 0,247 & 1 & 0,003 \\
& Non Pangan & 2,140 & 0,774 & 0,346 & 1 & 0,000
\end{tabular}

(Sumber : Data Olahan Hasil Penelitian, 2016)

Dari hasil analisis dari tabel 4 menunjukan bahwa secara statistik proporsi untuk pengeluran karbohidrat tidak signifikan, tetapi untuk pengeluaran non karbohidrat dan non pangan menunjukan pengaruh yang signifikan. Dengan koefesien regresi masing-masing untuk non karbohidrat 0,413 dan non pangan 0,774 , kondisi ini menunjukan makna bahwa setiap tambahan $1 \%$ pendapatan, masing-masing untuk non karbohidrat $0,413 \%$ dan non pangan $0,774 \%$. Sedangkan untuk proporsi pengeluaran karbohidrat tidak signifikan namun dengan demikian terdapat kecenderungan setiap kenaikan $1 \%$ pendapatan akan menambah proporsi pengeluaran untuk pangan karbohidrat sebanyak $0,115 \%$. Pada hasil analisis dapat ditulikan persamaan sebangai berikut :

$$
\begin{aligned}
& \mathrm{Y} 1=13,199 \cdot \mathrm{X}^{0,0607} \\
& \mathrm{Y} 2=8,671 \cdot \mathrm{X}^{0,616 \mathrm{U}} \\
& \mathrm{Y} 3=2,140 \cdot \mathrm{X}^{0,8887}
\end{aligned}
$$


Dengan $\mathrm{R}_{1}=0.026, \mathrm{R}_{2}=0.247, \mathrm{R}_{3}=0.346$. ini memberikan makna bahwa untuk model pertama variabel pendapatan $(\mathrm{X})$ dapat menerangkan variabel konsumsi karbohidrat $\left(\mathrm{Y}_{1}\right)$ sebesar 2,6\% dan sisanya $(97,4 \%)$ dari ditentukan dari oleh variabel lain diluar model, selanjutnya untuk model kedua variabel pendapatan $(\mathrm{X})$ dapat menerangkan variabel konsumsi non karbohidrat $\left(\mathrm{Y}_{2}\right)$ sebesar $24,7 \%$ dan sisanya sebesar $(75,3 \%)$ ditentukan oleh variabel lain diluar model, dan sedangkan untuk model ketiga variabel konsumsi non pangan $\left(\mathrm{Y}_{3}\right)$ sebesar $34,6 \%$ dan sisanya sebesar $(65,4 \%)$ ditentukan oleh variabel lain diluar model.

Secara tabulasi menunjukan bahwa proporsi terbesar penggunaan pendapatan karet secara berurutan adalah untuk pangan non karbohidrat $41 \%$, non pangan $38 \%$ dan pangan karbohidrat $21 \%$. Untuk pengaruh pendapatan terhadap pangan karbohidrat tidak signifikan, ini dikarenakan untuk pangan karbohidrat untuk signifikanya sebesar 0, 368 melebihi tingkat signifikan dengan $(\mathrm{a}=0,05)$. Hal ini untuk proporsi pengeluaran pangan karbohidrat dengan koefesien regresi 0,0607 dengan konstanta 13,199. Artinya bahwa setiap kenaikan $1 \%$ pendapatan, secara non signifikan akan menambah proporsi konsumsi untuk karbohidrat sebesar $0,0607 \%$. Sedangkan untuk pangan non karbohidrat dan non pangan secara signifikan dipengaruhi oleh pendapatan dengan nilai signifikan untuk pangan karbohidrat sebesar 0,003 dan untuk konsumsi non pangan sebesar 0,000 hal ini untuk konsumsi pangan karbohidrat dan non pangan lebih kecil dari tingkat signifikan dengan $(a=0,05)$ dengan koefesien regresi 0,6160 dengan konstanta 8,671. Artinya bahwa setiap kenaikan $1 \%$ pendapatan secara signifikan akan menambah proporsi pengeluaran untuk pangan non karbohidrat sebesar 0,6160 \% dan untuk konsumsi non pangan sebesar 0,8887. \%.

Berdasarkan dari perhitungan di atas dapat disimpulkan bahwa, secara signifikan semakin tinggi pendapatan, maka proporsi pengeluaran untuk non karbohidrat dan non pangan akan meningkat. Selanjutnya, untuk konsumsi pangan karbohidrat bahwa semakin tinggi pendapatan, maka secara non signifikan untuk konsumsi pangan karbohidrat akan meningkat. Jika dikaitkan dengan teori Engel, fakta ini menunjukan bahwa makanan pokok (beras dan umbi-umbian) dan tembakau (rokok) memiliki infioritas yang tertinggi di antara konsumsi pangan lainya. Artinya semakin besar tingkat pendapatan rumahtangga maka alokasi (proporsi) pendapatan yang digunakan untuk konsumsi beras dan rokok semakin kecil. Sebaliknya semakin rendah tingkat pendapatan rumahtangga, maka alokasi (proporsi) pendapatan yang digunakan untuk beras semakin meningkat.

Pendapat serupa sejalan dengan hasil penelitian Humaidi, (2015) bahwa, semakin rendah tingkat pendapatan ekonomi masyarakat, semakin tinggi presentasi energi yang digunakan berasal dari karbohidrat atau beras, karena energi dari karbohidrat termasuk yang paling murah harganya. Sedangkan Hasil penelitian menunjukan semakin tinggi tingkat pendapatan maka untuk pangan karbohidrat secara non signifikan akan meningkat dan secara signifikan untuk proporsi pengeluaran untuk non karbohidrat dan non pangan meningkat.

\section{KESIMPULAN DAN SARAN \\ Kesimpulan}

Berdasarkan hasil penelitian Hubungan Tingkat Pendapatan Petani Karet dengan Pola Konsumsi Rumahtangga di Desa Marga Sakti Kecamatan Muara Kelingi Kabupaten Musi Rawas, dapat disimpulkan beberapa hal sebagai berikut :

1. Tingkat pendapatan rumahtangga petani karet dan petani karet dan sawit, rata-rata petani karet Rp. 32.444.211 atau $45 \%$ dan pendapatan petani karet dan sawit rata-rata Rp. 54.694.286 atau $55 \%$. Dengan demikian bahwa pendapatan petani yaitu $55 \%$ tergantung dari komoditi karet dan sawit.

2. Semakin tinggi tingkat pendapatan, maka secara non signifikan proporsi pengeluaran untuk pangan karbohidrat akan meningkat dan secara signifikan untuk proporsi pengeluaran untuk non karbohidrat dan non pangan akan meningkat.

\section{Saran}

Dari hasil penelitian bahwa tingkat pendapatan petani tertinggi berasal dari usahatani karet dan sawit, sedangkan untuk pengeluaran petani tertinggi yaitu pengeluaran untuk beras, untuk melihat dari hasil pengeluaran maka diharapkan untuk petani mengubah pola konsumsi pangan karbohidrat ke pangan karbohidrat non beras. 


\section{DAFTAR PUSTAKA}

[BPS] Badan Pusat Statistik. (2013) 'Hasil Sensus Pertanian 2013', in. Jakarta. Available at: http://st2013.bps.go.id/st2013esya/booklet/st1802.pdf.

Cicih, L. H. M. (2011) 'Pengaruh Perilaku Ibu Terhadap Status Kesehatan Anak Baduta di Provinsi Jawa Tengah', Sari Pediatri, 13(1), pp. 41-47.

Criswardani S. (2005) 'Memahami Kemiskinan Secara Multidimensional', JMPK, Volume_8/V.

Humaidi, E. and Amin, Zaini, N. S. (2015) 'Pola Pengeluaran Rumah Tangga Petani Karet Di Desa Binjai Kecamatan Muara Kelingi', SOCIETA, IV(1), pp. 54-58. Available at:

https://www.google.com/url?sa=t\&rct=j\&q=\&esrc=s\&source=web\&cd=1\&cad=rja\&uact=8\&ved=2 ahUKEwj0u8XJ_I_iAhWMQo8KHXQ5BAkQFjAAegQIARAB\&url=http://jurnal.umpalembang.ac.id/societa/article/view/227\&usg=AOvVaw20_6heScNBZxeP7z9fZVL6.

Kadariah (2002) Analisis Pendapatan Nasional. Jakarta: Bina Aksara.

Malayu S.P Hasibuan (2012) 'Manajemen Sumber Daya Manusia. . pp : 141 -150', Jakarta: PT.Bumi Aksara, 1, pp. 141 - 150. doi: 10.1016/j.chemosphere.2018.05.062.

Perkebunan, D. J. (2014) Produksi, Luas areal dan Produktifitas Perkebunan Indonesia. Kementrian Pertanian Republik Indonesia. Jakarta: Kementrian Pertanian Republik Indonesia.

Suyastiri, N. M. (2008) 'Diversifikasi Konsumsi Pangan Lokal Berbasis Potensi Lokal dalam Mewujudkan Ketahanan Pangan Rumahtangga Pedesaan Kecamatan Semin Kabupaten Gunung Kidul', Ekonomi Pembanguanan, 13 No 1, pp. 56-60. 